\title{
Survival Mode: The Stresses and Strains of Computing Curricula Review
}

\author{
Grace Tan and Anne Venables \\ Victoria University, Melbourne City, Australia
}

\author{
Grace.Tan@vu.edu.au Anne.Venables@vu.edu.au
}

\section{Executive Summary}

In an ideal world, review and changes to computing curricula should be driven solely by academic concerns for the needs of students. The process should be informed by industry accreditation processes and international best practice (Hurst et al., 2001). However, Australian computing curricular review is often driven by the need for financial viability of programs with declining student numbers as much as concerns for academic merit.

Worldwide there remains a strong job market and high demand for computing professionals (Liu, 2007; Melymuka, 2006), which predicates an impending IT workforce shortage. However, comput ing programs currently do not attract students due to perceived problems of the inadequacy of courses to prepare students sufficiently to cope with the practical challenges in current technologies adoption, to acquire strong communication skills and business aptitude (Taft, 2007), to foster problem solving skills, and to find the relevance of program contents to specific occupations. Therefore, comput ing curricula wishing to attract students need to have specialized studies that are of industrial strength that are updated regularly to reflect the progress in the discipline (Finkelstein \& Hafner, 2002; Lui, 2007). Yet the challenge for universities is to weigh this need against preparing students to be universal and lifelong learners.

Given the impetus to be financially independent, the greatest challenge since 2004 for the School of Computer Science and Mathematics at Victoria University, Melbourne, has been the steady decline in both local and international student numbers. In response, between 2004 and 2006 the School underwent various restructurings, reviews, and assessments to meet government legislative requirements, professional accreditation needs and to capture new market share. In 2007, cont inued poor enrolment numbers threatened the School's long term sustainability necessit ating urgent strat egic analysis and decision making surrounding the future of computing programs. It was decided that a new and innovative program embracing emerging comput ing paradigms was needed to attract potential students. The proposed program structure would be based upon input from industry representatives, senior academics, and government reports whilst operat ing within existing budget constraints. Essentially, existing programs were to be condensed into a core offering with six specializations in a) Interac-

Material published as part of this publication, either on-line or in print, is copyrighted by the Informing Science Institute. Permission to make digital or paper copy of part or all of these works for personal or classroomuse is granted without fee provided that the copies are not made or distributed for profit or commercial advantage AND that copies 1 ) bear this notice in full and 2) give the full citation on the first page. It is permissible to abstract these works solong as credit is given. To copy in all other cases orto republish or to post on a serveror to redistribute to lists requires specific permission and payment of fee. Contact Publisher@InformingScience.org to request redistribution permission. tive Digital Media and Game Development, b) Web T echnologies and Mobile Computing, c) IT Security, d) Computational Finance, e) Business Intelligence and Service Computing, and f) Aviation Technology. The choice of specializations was made to firstly incorporate the major characteristics and paradigm shifts in the ICT industry, secondly to cater for the broad diversity of student 
interests, and thirdly to capitalize on historical strengths. Through these specializations, the program offers prospective students the necessary skills needed for fut ure predicted employment shortages. With adequate marketing, it is hoped that the proposed new structure will allow for quick responses to external positive changes in demand and thus at tract student interest.

Keywords: computing education, IT education, academic review, curriculum development.

\section{Introduction}

In an ideal world, review and changes to computing curricula should be driven solely by academic concems for the needs of students. The process should be informed by industry accreditation processes and international best practice (Hurst et al., 2001). The reality in Australia is quite different. In their telling report, What Drives Curriculum Change? Gruba, Moffat, Sondergaard and Zobel (2004) conclude that "changes are driven by individuals, politics, and fashion more than they are driven by academic merit and external curricula." Optimistically, they comment that, despite widespread difficulties encountered in Australian higher education institutions, overall computing academics remain confident that the right changes are being made regarding curricula development.

Over the past twenty years there have been "seemingly never ending waves of amalgamation, restructuring and re-organisation of Australian universities" (Saunders, 2006). The amalgamations of technical and higher education institutions began in early 1990s, accompanied by governmental changes to funding models for both sectors, which have impacted greatly on the curricula design and how courses can be conducted (Skilbeck \& Connell, 1999). Today, the bott om line is that education institutes are expected to be financially independent. Within each institute, individual operat ing units need to attract enough students, both local and full-fee paying international students, to justify their existence. Otherwise, they will face either merger or dissolution. A consequence of the need for fiscal sustainability of programs has seen many institutes begin franchise arrangements with offshore partners for the delivery of Australian computing courses.

Against the backdrop of the $\mathrm{Y} 2 \mathrm{~K}$ scare and dot.com bust, computer science student enrolments have been undergoing a dramatic decline worldwide. For instance, between 2001 and 2005 the number of freshmen who expressed an interest in majoring in computer science has plummeted by 59 percent at one Californian university (Foster, 2005). In Australia, since 2002 the numbers of ICT students has dropped 19\% nationally (Multimedia Victoria [MMV], 2007). This alarming trend triggered the State Government of Victoria to commission a survey of the 217 students who planned to go onto university studies, to state their study preferences. Worryingly, the survey found that only $13 \%$ of males said they would study IT, whereas no female said that she planned to study IT at university (MMV, 2004).

This trend of diminishing student enrolments, together with the need for financial independence, is having an adverse effect on many Australian computing faculties, undermining their cont inuing survival. Accordingly, this paper looks in detail at the current challenges faced by IT faculties, and then describes the local situation for the School of Computer Science \& Mathematics at Victoria University. The impact of poor student enrolments has had upon computing curricula is described along with the various interventions undertaken to alleviate the problem. The paper outlines the challenges we faced during the process, the rationale for the proposed response and the consequent alignment of the computing curricula.

\section{Current Challenges in Computing and IT Programs}

Worldwide there remains a strong job market and high demand for computing professionals (Liu, 2007; Melymuka, 2006). In the United States, Dychtwald, Erickson and Morison (2006) in their book Workforce Crisis: How to Beat the Coming Shortage of Skills and Talent have predicted an 
impending IT workforce crisis for the coming decade due to the declining enrolments in both undergraduate and graduate IT programs. In Australia, where the ICT industry generates revenues of AUD 65.7 billion (USD 60 billion) or $8.7 \%$ of GDP, the federal government has identified the shortage of IT students as an issue requiring remedial action in the near future. Likewise in the State of Victoria, the second largest provider of ICT skill in the country, government cont inues to invest in possible countermeasures to steady the decline of skilled workers in the IT industry (MMV, 2004).

If computing is such a vibrant field, then why does it not attract students to ICT tertiary studies? According to the ICT Skills Research report, the most positive aspect of the ICT career is the opportunity to work with the latest technologies (MMV, 2007). Amongst American IT programs, Finkelstein and Hafner (2002) identify the existence of a professional practices gap in that the programs do not prepare students sufficiently to cope with the practical challenges in current technologies adoption. Additionally, it is widely recognized that computer science undergraduate studies do not adequately prepare students for proficiency in the workforce where they need strong communication skills and business aptitude (T aft, 2007). Unit ed Kingdom employers want graduates with technical knowledge, intellect, and a willingness to learn (Harvey, Moon, Geall, \& Bower, 1997), whereas in Australia research on employer sat isfaction with graduate skills has found that computer science graduates lack problem solving and business communication skills (AC Nielsen Research Services, 2000). It has also been argued that students are not going into computing courses as they cannot relate course content to specific occupations. A Finnish study of staff and student att itudes to the computing discipline noted that students were more interested in how comput ing related to business than were their lecturers (Ylijoki, 2000) and there is a need to showcase exemplars of qualified people working in IT to students (Victoria University [VU], 2007).

Yet the mission of the universities is to educate and prepare students to be universal lifelong learners, rather than to prepare them for job specific tasks. Given the reality and the necessity for any academic program to be sustainable, it has to have students enrolled. Therefore, it is essential that any IT program should focus on the balance between vocational and intellectual demands in order to enhance graduate employment prospects. The curriculum should ensure that students are prepared effectively for fut ure employment by responding to the education and training needs of industry and the community. Comput ing programs wishing to attract students need to have specialized studies that are of industrial strength and are updated regularly to reflect the progress in the discipline (Finkelstein \& Hafner, 2002; Lui, 2007).

Without question the most significant challenges with respect to the design of IT curricula relates to the objectives of excellence and relevance. The engagement with industry and the community is required to determine the relevance of the program to meet their needs in the fut ure. As well, external factors such as government funding for higher education, university and faculty strat egic plans, domestic and international student demand, and professional accreditation demands, all come to bear upon academic decisions for program development (T an \& Venables, 2007).

\section{Our Situation}

Given the impetus to be financially independent, the greatest challenge for the School of Computer Science and Mathematics at Victoria University, Melbourne has been the steady decline in both local and international student numbers across the board in all of our courses. This has occurred despite the anecdotal evidence of a growing local demand for computing graduates and the growth in IT program offerings. To arrest this decline and to remain competitive, our course offerings have undergone several major revisions in recent years. 


\section{Historical Perspective}

Prior to 2004, the School of Computer Science and Mathematics enjoyed strong student demand for each of its three core undergraduate courses: Bachelor of Science in Computer Science, Bachelor of Science in Computer \& Mathematical Sciences, and the Bachelor of Science in Computer Science and Aviation which attracted students both onshore and offshore (in Hong Kong, China and Malaysia). Since then, several factors, such as the early symptoms of the decline in student numbers, changes in national legislation, the meet ing of University requirements and the need for professional body accreditation, have triggered what seems to be unending rounds of course restructuring and documentation at our inst itution.

Up until 2003, the local student numbers had remained steady for a number of years while our offshore programs cont inued to grow. In 2004, concern was raised when local student enrolments failed to meet the targeted enrolment numbers. Subsequently, a review of our existing offerings was made with the view to attract ing new students, and various specializations of our traditional computer science programs were seen to hold promise.

Firstly, the rapidly developing field of internet technologies was seen as a priority area that would be attract ive to new school leavers and overseas students. A new program was proposed to include topics on web data management, web-based services, and internet applications. As well, an additional program where students develop IT specialist skills and the conceptual understandings to design, install, configure, and manage various advanced data management technologies was proposed. Finally, to capitalize on our in-house expertise, a program coupling both computing and mathematical sciences with a focus on finance and risk management was designed to capture the niche market of financial computing mathematics. There is no other undergraduate course in Australia and, indeed, very few internationally, that seek to combine finance with both disciplines of computer science and mathematics. As a result, three additional undergraduate programs Bachelor of Science in Information T echnology, Bachelor of Science in Internet Technologies and Applications and Bachelor of Science in Computational and Financial Mathematics - were scoped and then documented before their introduction in March 2005 (VU, 2005).

In parallel with the introduction of these three new programs, a major course review was undertaken to comply with the Australian government's Higher Education Support Act (HESA) 2003. This legislation mandated and regulated the conditions under which tertiary institutions were able to be run and funded. It impacted all Australian universities, resulting in Victoria University adopting a uniform system for unit sizes and associated credit points across all program offerings. For our undergraduate programs, an extensive academic review revealed no uniformity in the unit values within and across year levels, and it exposed inconsistencies in the number of units for different year levels within the degrees. The adoption of the HESA compliant model necessitated the retrofitting of existing programs so that they could be collapsed from 29 units of study to 24 whilst maintaining the overall the breadth and depth of syllabi. The first implementation of the new HESA compliant programs took effect for the academic year commencing in March 2006 (T an \& Venables, 2007).

In addition to meeting HESA requirements, the University itself has placed considerable pressure upon our program offerings by insisting that each program be financially sustainable in both onshore and offshore deliveries. To police this requirement, regular extensive program reviews are scheduled that examine the demand and the viability of each course offering, together with the contents, for relevance and appropriateness to the different student cohorts. All Schools are expected to rationalize their programs by merging any that are similar. Additionally, content is examined for compliance with internal university policies, for instance, the embodiment of core graduate attributes that must be developed progressively throughout the curricula (Miliszewska \& Tan, 2004). 
All our courses came due for professional accreditation through the Australian Computer Society (ACS) in 2006. The ACS is the professional body responsible for the assessment of all higher education ICT courses accreditation ensuring international credibility and enhancing the marketability of programs (ACS, 2003; Ramakrishnan, 2007). Based upon the American Association for Computing Machinery (ACM) models, an ACS accreditation's overriding task is to examine all aspects in the provision of a quality ICT education program designed to produce competent graduates. The three main foci of assessment are the structure and content of curricula, the resources of the teaching and leaming environments, and the quality assurance processes in place at the university (ACS, 2003). The key steps included collection of data, completion of a suite of ACS documentation templates by the School, and the assembling of an assessment panel by the ACS, followed by the panel's site visit and the final report of the ACS recommendations. Although the accreditation was not in itself a full review or audit of courses, it did help identify key areas that needed immediate attention and some forward planning.

The various restructurings, reviews, and assessments of the academic programs throughout the years from 2004 to 2006 have entailed enormous amounts of goodwill, time, energy, and dedication from staff of the School of Computer Science \& Mathematics who volunteered their time without adjustments to course loads. In retrospect, the introduction of the three new programs along with the changes made to content in units of study did little to arrest the decline in applying students.

Moving forward with no immediate increase in student demand in sight, it became apparent that we had too many programs with too few students to ensure long term sustainability. A critical reappraisal of our situation was needed for survival. An immediate short term strat egy of pruning existing units of study offerings was done and in the longer term, a radical computing curriculum review was called for to tap new local and international markets for students. In a nut-shell, a total curricula review was undertaken to find a program structure that would translate into an increase in student numbers

\section{Current Perspective}

In response, an analysis of the local situation was made in comparison to computing course offerings worldwide. Our researches found, perhaps not surprisingly, that successful programs seemed to be able to differentiate themselves from their compet it ors by fulfilling the needs of the community and by meet ing their expectations (Novotny \& Doucek, 2007; Sharda, 2007). Suggested avenues for exploration were successful programs at other institutions in interactive digital media, cross disciplinary applications like health informatics and embedded systems informatics, entertainment technologies, and game development (Clemson University, 2007; Monash University, 2007).

Locally, we sourced advice about possible fut ure curricula directions through our Course Advisory Board, which is comprised of industry representatives, professorial academic staff from other institutions, and our senior academics. To gain insights into fut ure students' preferences for tertiary studies we have relied heavily upon a set of investigations and reports conducted at a state funded level by Multimedia Victoria (MMV, 2004, MMV, 2007).

The mission for the course development team was to derive a new and innovative program structure that would prove attractive to potential students as our immediate concem was to increase our student intake. The proposed program would need to embrace emerging computing paradigms base d upon sound academic principles and be able to operate within the existing budget constraints. 


\section{The Response}

With the immediate economic need to reduce the number of program offerings but still provide prospective students the opport unities to acquire different knowledge and skill sets, a decision was made to merge the current five exist ing courses (SBCO, SBIT, SBIA, SBCA, and SBCF) into one main program. The program, to be named Bachelor of Applied Science in Computing, would have six specializations built within the structure. For the proposed program, there would be a noticeable shift in emphasis from our traditionally theoretical offerings to a program with a more practical orientation necessitating the addition of the word 'Applied' to the name of the award. In the new structure, specialized studies to be offered are: a) Interactive Digital Media and Game Development, b) Web Technologies and Mobile Computing, c) IT Security, d) Computational Finance, e) Business Intelligence and Service Computing, and f) Aviation Technology.

The choice of specializations was made firstly to incorporatethe major characteristics and paradigm shifts in the ICT industry, secondly to cater for the broad diversity of student interests, and thirdly to capitalize on our hist orical strengths. The revised course structure addresses the issue of accommodating the latest developments in the areas of ICT with the inclusion of specializations that allow students to progress to the top four ICT career options that students are interested in: game developer, graphics designer, Web or multimedia designer, and Web developer (MMV, 2007, p. 24). As well, there have been forecasted future skill shortages for the ICT specializations of security and in business applications and service computing(Australian Workplace, 2007). Further, the computational finance stream combines statistics and computing with a focus on finance and risk management, and in overseas markets like China graduates are sought with this combined expertise. Locally, aviation and comput ing studies combined have historically been a good attractor for students, and therefore the aviation technology stream capitalizes upon this interest.

The proposed Bachelor of Applied Science in Computing program structure, as detailed in Table 1 , comprises a total of 24 units of study over a three year program. Notice that, irrespective of a student's choice of specialization, there are 15 common units that must be undertaken. For program completion, the remaining 9 units complete the specialization studies of a chosen stream. In each stream, there are a set of stream required units of study together with some stream suggested electives. For program completion, it is understood that a student will pass the 15 common units together with the required units of their stream specialization and any necessary electives to total 24 units of study overall. The specializations for each stream are listed in Table 2.

For economic reasons, it was critical to streamline the number of units that could be offered in the new proposed structure without sacrificing the breadth of coverage of the combined programs. From an administrative standpoint, having all students study a set of common core units means that class sizes become more viable. As well, amongst the specialization streams it should be noted that required units of study in one stream may also be used as sugge sted electives in another stream, again underlining that the need to cater for the diverse interests of our potential students within current financial constraints. 
Table 1 -Proposed Bachelor of Applied Science in Computing program structu re

\begin{tabular}{|c|c|c|c|}
\hline Semester 1 & $\begin{array}{l}\text { Credit } \\
\text { Points }\end{array}$ & Semester 2 & $\begin{array}{l}\text { Credit } \\
\text { Points }\end{array}$ \\
\hline \multicolumn{4}{|c|}{ Year 1} \\
\hline $\begin{array}{l}\text { RCM1115 Comp Systems and Architec- } \\
\text { ture }\end{array}$ & 12 & RCM1113 Multimedia Systems & 12 \\
\hline RCM1311 Programming 1 & 12 & RCM1312 Programming 2 & 12 \\
\hline RCM1613 Applied Statistics 1 & 12 & RCM1713 Computer Algorithms & 12 \\
\hline RCM1711 Math Foundations & 12 & One elective & 12 \\
\hline \multicolumn{4}{|c|}{ Year 2} \\
\hline RCM2211 Database Systems 1 & 12 & $\begin{array}{l}\text { RCM2111 Data Communications \& } \\
\text { Networks } 1\end{array}$ & 12 \\
\hline $\begin{array}{l}\text { RCM2311 Objected Oriented Program- } \\
\text { ming } 1\end{array}$ & 12 & Stream required unit & 12 \\
\hline RCM2312 Software Engineering 1 & 12 & \multirow[t]{2}{*}{ Two electives } & \multirow[t]{2}{*}{24} \\
\hline One elective & 12 & & \\
\hline \multicolumn{4}{|c|}{ Year 3} \\
\hline ACE3145 Professional Communication & 12 & RCM3002 Project 2 & 12 \\
\hline RCM3001 Project 1 & 12 & $\begin{array}{l}\text { RCM3111 Modern Computer Net- } \\
\text { works and Pervasive Computing }\end{array}$ & 12 \\
\hline Two stream required units / electives & 24 & Two stream required units / electives & 24 \\
\hline
\end{tabular}

Table 2 -Required and elective units for stream specialization

\begin{tabular}{|c|c|c|}
\hline $\begin{array}{l}\text { Interactive Digital Media and } \\
\text { Game Development }\end{array}$ & $\begin{array}{l}\text { Internet Technology and } \\
\text { Mobile Computing }\end{array}$ & IT Security \\
\hline $\begin{array}{l}\text { Stream Required Units: } \\
\text { RCM2213 Computer Graphics } \\
\text { and 3D Modelling } \\
\text { RCM3112 Human Computer } \\
\text { Interaction and Game Develop- } \\
\text { ment } \\
\text { RCM3970 Computer Graphics } \\
\text { for Game Programming } \\
\text { RCM3980 Virtual Reality and } \\
\text { Smart Environment } \\
\text { Suggested Electives: } \\
\text { RCM3312 Intelligent Systems } \\
\text { RCM3313 Quality Assurance } \\
\text { and Software Testing }\end{array}$ & $\begin{array}{l}\text { Stream Required Units: } \\
\text { RCM2930 Game Engines and } \\
\text { Online Games } \\
\text { RCM3950 Development of } \\
\text { Web and Mobile Applications } \\
\text { RCM3820 Web Computing and } \\
\text { Services } \\
\text { RCM3960 Internet, Wireless } \\
\text { and Computer Security } \\
\text { RCM3980 Virtual Reality and } \\
\text { Smart Environment }\end{array}$ & $\begin{array}{l}\text { Stream Required Units: } \\
\text { RCM2112 Operating System and } \\
\text { System Security } \\
\text { RCM3720 Cryptography and } \\
\text { Computer Security } \\
\text { RCM3960 Internet, Wireless and } \\
\text { Computer Security } \\
\text { RCM2511 Image Processing and } \\
\text { Pattern Recognition }\end{array}$ \\
\hline
\end{tabular}




\begin{tabular}{|c|c|c|}
\hline Computational Finance & $\begin{array}{l}\text { Business Intelligence and } \\
\text { Service Computing }\end{array}$ & Aviation Technology \\
\hline $\begin{array}{l}\text { Suggested electives: } \\
\text { RCM2612 Financial Data } \\
\text { Analysis and Forcasting } \\
\text { RCM2915 Practical Financial } \\
\text { Optimization } \\
\text { BEO2*** Technical Analysis } \\
\text { and Trading Rules of Financial } \\
\text { Instruments (appropriat e unit } \\
\text { numbering to be decided) } \\
\text { BAO1101 Accounting for Deci- } \\
\text { sion Making } \\
\text { BEO1103 Microeconomic Prin- } \\
\text { ciples } \\
\text { BEO1104 Macroeconomic } \\
\text { Principles } \\
\text { RCM3413 Financial Engineer- } \\
\text { ing } \\
\text { RCM3911 Financial Simulation } \\
\text { and Applications } \\
\text { RCM3940 Financial Risk } \\
\text { Analysis and Modelling } \\
\text { BAO3307 Corporate Finance } \\
\text { BAO3402 International Bank- } \\
\text { ing and Finance } \\
\text { BAO3403 Investment and Port- } \\
\text { folio Manag ement }\end{array}$ & $\begin{array}{l}\text { Stream Required Units: } \\
\text { RCM2218 Enterprise Database } \\
\text { System and ERP } \\
\text { RCM3311 Enterprise Inform a- } \\
\text { tion System Development } \\
\text { RCM3115 Enterprise Wide } \\
\text { Computing and Service Com- } \\
\text { puting } \\
\text { Suggested Electives: } \\
\text { RCM3950 Development of } \\
\text { Web and Mobile Applications } \\
\text { RCM3820 Web Computing and } \\
\text { Services }\end{array}$ & $\begin{array}{l}\text { Stream Required Units: } \\
\text { RCA1010 Introductory Aviation } \\
\text { RCA2020 Meteorology and Hu- } \\
\text { man factors for the CPL } \\
\text { RCA2030 Navigation and Flight } \\
\text { law for the CPL } \\
\text { RCA2040 Aerodynamics and } \\
\text { Aircraft General Knowledge for } \\
\text { the CPL } \\
\text { RCA2060 Operations Perform- } \\
\text { ance and Flight Planning for the } \\
\text { CPL } \\
\text { RCA3010 Instrument Rating } \\
\text { (IREX) } \\
\text { RCA3030 Meteorology and Hu- } \\
\text { man Factors for the ATPL } \\
\text { RCA3040 Flight Planning, Navi- } \\
\text { gation and Air law for the ATPL } \\
\text { RCA3060 Aerodynamics and } \\
\text { Aircraft Systems for the ATPL }\end{array}$ \\
\hline
\end{tabular}

\section{Curriculum Differentiation}

The new proposal preserves one of the hist orical strengths of all our original programs - the industry based final year comput ing project units. These capstone projects give students the opportunity to work on a real-life software development tasks where they experience the practical challenges of building software systems whilst appreciating the needs of a business client. In this environment, students not only need to use their technological knowledge but also need to develop their communication, teambuilding, and problem solving skills. When dealing with clients, students develop negotiation and listening abilities, and they hone their presentation and marketing skills.

At the sametime, the program allows the School to offer units that capturethe most likely needed skills for graduates in the near future. Brandel (2007) identified that the most demand for skills will be in the area of machine learning, mobilizing applications, wireless networking, humancomputer interface, project management, general networking skills, network convergence, open source programming, business intelligence, embedded security, .Net, $\mathrm{C}++$, and Java. This view is reinforced by a report of the Australian Workplace (2007) which identified skills in demand that are also covered by our structure. These skills include Oracle, data warehousing, C++, Java programming, J2EE, .Net technologies, ASP, security, and risk management.

Another consideration in designing the new proposal was an awareness of the academic rigor as required for ACS accreditation of our program. For marketing purposes, both locally and internationally, it is crucial that graduates satisfy the requirements of a professional level of accreditation, thereby enhancing their employment outcomes. 


\section{Conclusions}

The comput ing programs at Victoria University continue to face the same local, national, and intemational challenges as do other higher education providers of IT programs within Australia as it strives to maintain relevancy in its program offerings. Due to external factors, including the decline in student demand, the School of Computer Science and Mathematics has found itself in a more precarious position financially. University procedures have illuminated inefficiencies with respect to class sizes and individual academic workloads, and it has become imperative that a strat egy be found to turn round the financial situation. Recognizing the major drivers for change in its curriculum and identifying its strengths, weaknesses, opportunities, and threats in the recent computing curricula review is critical to the fut ure survival of its computing programs within the School.

The question remains, will the above proposed structure lead to an increase in student demand? The success, or otherwise, is heavily dependent upon an increased market presence. To this end, School academics have recently become more actively involved in the promotional activities locally and abroad. For instance, specialized bilingual brochures have been developed to specifically target offshore cohorts and relationships with local feeder high schools cont inue to be nurtured. With adequate marketing, it is hoped that the proposed new structure will allow us to respond quickly to external positive changes in demand and thus attract students to our programs.

The information we have from our researches from our staff net works have supported the adoption of the new program structure. It has been reported that game development courses in other universities have very good intakes (Metlikovec, 2007), which supports our belief that there is strong student interest for streams in Interactive Digital Media and Game Development, Web Technologies and Mobile Computing and IT Security. In fact, it is hoped that they will become the flagship offerings forthe School. As well, we expect to further expand our offshore activities and become more involved in the expanding Chinese education market and expect that the Computational Finance stream will be very attractiveto this clientele. This stream in Computational Finance uniquely differentiates us from other Australian universities as does our Aviation Technology stream. As well, forecasted industry shortages in security and in business applications and service computing should convert to increased student interest in careers in these areas. The proposed program aims to increase student intake; however, staff realize that little can be done about cyclical and global forces that impact considerably upon our situation. In this instance, staff wish to remain in charge of their own destiny as to do nothing would be no more risky than leaving the School's future in the hands of University administrators.

\section{References}

AC Nielsen Research Services. (2000). Employer satisfaction with graduate skills. Research report 99/7. Department of Education, Training and Youth Affairs (DETYA).

ACS - The Australian Computer Society. (2003). Accreditation of courses at the professional level Guidelines for applicants. ISBN $090992564 \mathrm{X}$.

Australian Workplace. (2007). Skills in demand. Retrieved October 2007 from http://www.workplace.gov.au/workplace/Publications/LabourMark etAnalysis/Skillsindemand.htm

Brandel, M. (2007). 12 IT skills that employers can't say no to. Retrieved August 2007 from http://www.computerworld.com/action/article. do? command=viewArticleBasic\&articleId=9026623\&so urce $=$ NLT CAR\&nlid $=5$

Clemson University. (2007). School of Computing. Retrieved September 2007 from

http://www.cs.clemson.edu 
Dychtwald, K., Erickson, T. J., \& Morison, R. (2006). Workforce crisis: How to beat the coming shortage of skills and talent. Harvard Business School Press.

Finkelstein, L., \& Hafner, C. (2002). The evolving discipline(s) of IT (and their relation to computer science): A framework for discussion. Retrieved October 2007 from http://www.cra. org/Activities/itdeans/finkelstein.pdf

Foster, A. (2005, May). Student interest in computer science plummets. Chronicle of Higher Education, 51(38).

Gruba, P., Moffat, A., Sondergaard, H., \& Zobel, J. (2004). What drives curriculum change? Proceedings of Sixth Australasian Computing Education Conference (ACE2004), Dunedin, New Zealand. Conferences in Research and Practice in In formation Technology, Vol. 30.

Harvey, L., Moon, S., Geall, V. \& Bower, R (1997). Graduates' work: Organisation change and students' attributes. Birmingham, Centre for Research into Quality (CRQ) and Association of Graduate Recruiter (AGR).

Hurst, J., Carbone, A., Eley, M., Ellis, A., Hagan, D., Markham, S., Sheard, J., \& Tuovinen, J. (2001). Teaching ICT: The report on learning outcomes and curriculum development in major university disciplines in Information and Communication Technology. Higher Education Division, Department of Education, Training and Youth Affairs.

Liu, J. (2007, May). Computing as an evolving discipline: 10 observations. Computer -IEEE Computer Society magazine. Retrieved in June, 2007 from http://www.computer.org/portal/site/computer/menuitem.5d61c1d591162e4b0efl bd108bcd45 f3/index. isp? \&pName $=$ computer level 1 articl e\&TheCat $=1015 \&$ path $=$ computer $/$ homepage/May $07 \&$ file $=$ pro fes $\underline{\text { sion. } x m l \& x s l=\text { article. } x s 1 \&}$

Melymuka, K. (2006, July 3). Workforce crisis: Preparing for the coming IT crunch. Computerworld. Retrieved in August, 2007 from http://www.computerworld.com/action/article.do? command=viewArticleBasic\&articleId=112240

Metlikovec, J. (2007, November 19). Game on for uni courses. Herald Sun.

Miliszewska, I., \& Tan, G. (2004). Realising core graduate attributes in computer science through a CPR (Collaboration-Participation-Relev ance) approach to teaching. Proceedings of the HERDSA Conference, Miri, Malaysia.

Monash University. (2007). School of Information Technology. Retrieved October 2007 from http://www.infotech.monash.edu.au

Multimedia Victoria (MMV). (2004). ICT skills research -Attitudes to ICT careers and study among 14-19 year old Victorians. Victorian Government, Department of In frastru cture, 9-12.

Multimedia Victoria (MMV) (2007). ICT Skills Research - Attitudes to ICT careers and study among 14-19 year old Victorians (Year 9-12). Retrieved September 2007 from http://www.mmv.vic.gov.au/uploads/downloads/Skills careers/ICT SkillsResearchFINALPDF.pdf

Novotny, O., \& Doucek, P. (2007). Is the ICT university degree the best option for being a success ful ICT pro fessional? Proceedings of Computer Science + Information Technology Education Conference (CSITEd 2007), November 16-18, 2007, Mauritius, 537-548. Retrieved from http://csited.org/2007/50NovoCSITEd.pdf

Ramakrishnan, S. (2007). Accreditation of Monash University Soffware Engineering (MUSE) Program, International Journal of Issues in Informing Science and Information Technology, 4, 73-89. Retrieved from http://proceedings.informingscience.org/InSITE2007/IISIT v4p073-089Rama272.pdf

Saunders, M. (2006, March). The madness and malady of manageri alism. Quadrant Magazine, L(3). Retrieved in March, 2007 from http://quadrant.org.au/php/article view.php? article id=1921

Sharda, N. (2007). Creating innovative new media programs: Need, challenges, and development fram ework. Proceedings of the International Workshop on Educational Multimedia and Multimedia Education, Augsburg, Bavaria, Germany. pp. 77-86. 
Skilbeck, M., \& Connell, H. (1999). Quality assurance and accreditation in Australia higher education. Department of Education, Training and Youth Affairs (DETYA).

Taft, D. (2007). Programming grads meet a skills gap in the real world. eWeek. Retrieved September 2007 from http://www.eweek.com/article2/0,1895,2178319,00.asp

Tan, G., \& Venables, A. (2007). The impact of Australian legislation upon an IT degree: Considerations and response. Proceedings of the 2007 Information Resources Management Association International Conference (IRMA2007), Vancouver, Canada, 70-73.

Victoria University (VU). (2005). Faculty of Science, Engineering and Technology Handbook 2005.

Victoria University (VU). (2007). Minutes of the School Advisory Board meeting.

Ylijoki, O-H (2000). Disciplinary cultures and the moral order of studying - a case study of four Finnish university departments. Higher Education. 39, 339-362.

\section{Biographies}

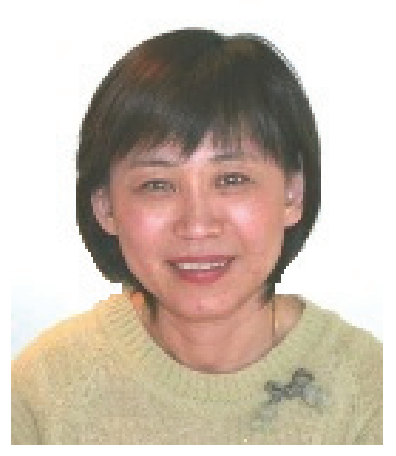

Grace Tan is a senior lecturer in Computer Science at Victoria University, Melbourne, Australia. Her research interests include investigations of innovative teaching methods, the development of graduate attributes, and issues related to female students in computing courses and Grace has published in these areas.

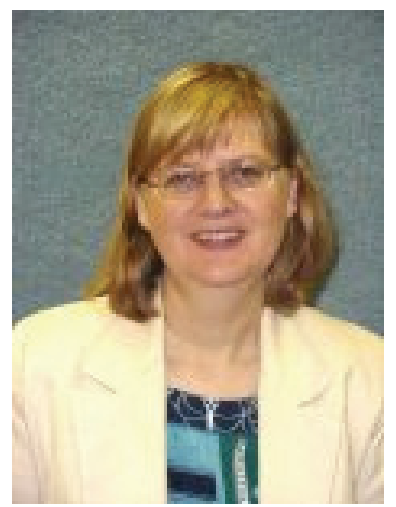

Anne Venables lectures in Computer Science at Victoria University, Melbourne, Australia. She has research and teaching interests in artificial intelligence and intelligence systems. Originally trained in Genetics, Anne spent several years as a secondary Science and Mathematics teacher before migrating into tertiary education. Anne is interested in innovations in education and has previously published in this field. 